

\title{
VOL. XXV.-1910.
}

THE

\section{JOURNAL OF LARYNGOLOGY,}

\section{RHINOLOGY, AND OTOLOGY;}

AN ANALYTICAL RECORD OF CURRENT LITERATURE

\author{
RELATING TO
}

\section{THE THROAT, NOSE, AND EAR.}

PUBLISHED MONTHLY.

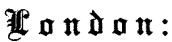

ADLARD AND SON, BARTHOLOMEW CLOSE. 


\section{THE JOURNAL OF LARYNGOLOGY, RHINOLOGY, AND OTOLOGY.}

Founded in 1887 by MORELL MACKENZIE and NORRIS WOLFENDEN.

Proprietors and Editors:

JOHN MACINTYRE, M.B., M.Ch., F.R.S.E.

ARTHUR SANDFORD, M.D., M.Ch.R.U.I.

DUNDAS GRANT, M.A., M.D., F.R.C.S.Eng.

W. MILLIGAN, M.D., M.Ch.

Controllina Editor:

DUNDAS GRANT, M.A.; M.D., F.R.C.S.Eng.

SUB-EDITOR :

DAN McKENZIE, M.D., F.R.C.S.E.

WITH THE CO-OPRRATION OE

Drs. Price-Brown (Toronto), Cartaz (Paris), Bryson Delavan (New York),

Dodd (Chicago), Donelan (London), Chayton Fox (London),

J. S. Frasar (Edinburgh), Gray (Glasgow), Guthrie (Liverpool), Grazzi (Florence),

Hicadet (Brussels), Middemass Hunt (Liverpool), Hutchison (Brighton),

Joal (Paris), Kelly (Glasgow), Lacoarret (Toulouse), Lichitwitz (Bordeaux),

Lieven (Aix-la-Chapelle), John N. Mackenzie (Baltimore),

Prof. Massei (Naples), McCall (Bournemouth), Meyjes (Amsterdam),

Myles (New York), Holger Myaind (Copenhagen), Chichele Nourse (London),

Porter (St. Louis), W. G. Porter (Edinburgh), Know les Renshaw (Manchester),

SaChs (Hamburg), Sajous (Philadelphia), Sendziak (Warsaw),

Lindeley Sewell (Manchester), Sota (Seville), StClair Thomson (London),

Purves Stewart (London), Hunter Tod (London), Alex. Tweedie (Nottingham),

Woods (Dublin), Write (London), Macleod Yearsley (London),

AND ZiEM (Dantzig). 


\section{LIST OF PLATES.}

Prame. TO Fack

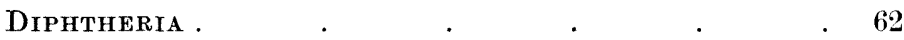

Plate. To Illustrate Messrs. W. G. Porter and J. M. Darling's REPORT .

Plates. To Illustrate Dr. A. A. Gray's Paper on Deaf-mutism

$227,228,230,232$

Plates. To Illustrate Dr. A. Brown Kelly's Paper on In-

Sufficiency of Palate . . . $\quad 287,345$

Plate of Portrait of the Late E. Cresswell Baber • 337

Plates. To Illustrate Dr. Bruce's and Mr. Fraser's Paper on MÉnière's SyndRome . . . . 398,400

Plate. To Illustrate Mr. G. S. Hett's Paper on The Capsule OF THE TONSIL . . . . . . . 564

\section{ILLUS'TRA'TIONS IN TEXT.}

Illustrating Dr. Brown Kelly's Paper on Insuffictency of the

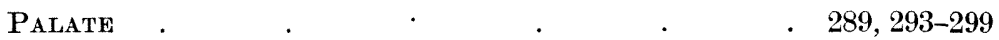

"VAPOROLE InHALER" . . . . . . . 504

Illustrating Mr. H. S. Hett's Paper on the Capsule of the

TONSIL . 


\title{
THE JOURNAL OF LARYNGOLOGY, \\ RHINOLOGY, AND OTOLOGY. \\ Founded in 1887 by MORELL MACKENZIE and NORRIS WOLFENDEN.
}

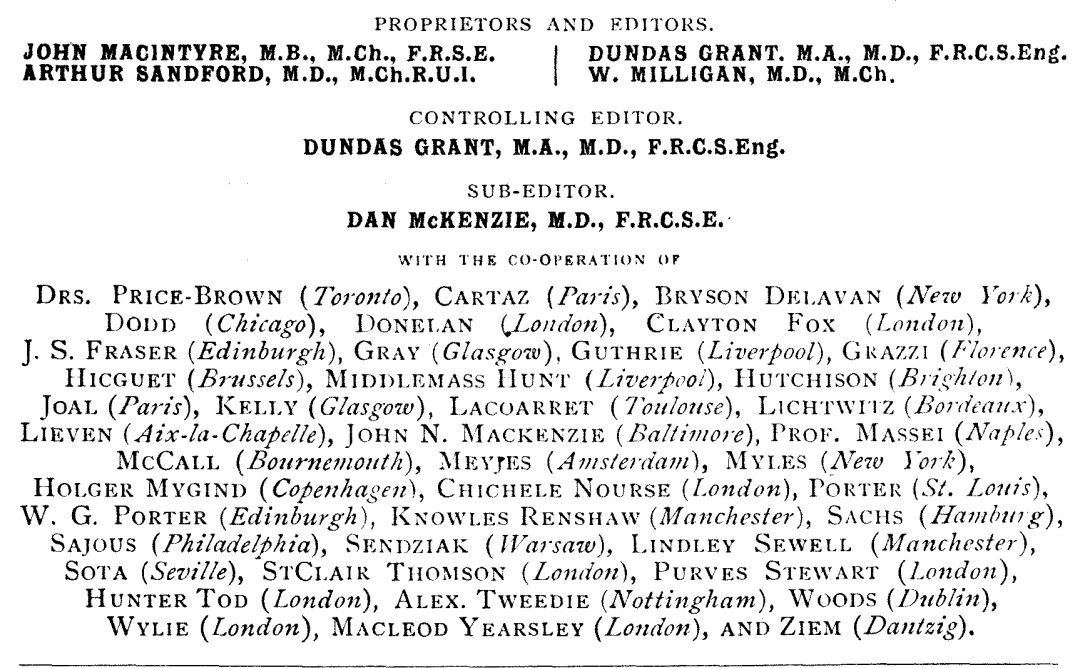

CONTRIBUTORS TO THIS NUMBER

\begin{tabular}{l|l|l} 
Dr. P. W. Williams. & Mr. Alex R. Tweedie. & Dr. Dundas Grant.
\end{tabular}

Dr. Thomas Guthrie. Dr. Dan McKenzie.

MEDICAL GRADUATES' COLLEGE

\section{AND \\ POLYCLINIC,}

22, Chenies Street, Gower Street, London, W.C.

\author{
HONORARY PRESIDENT: \\ Sir JONATHAN HUTCHINSON, F.R.S., LL.D. \\ PRESIDENT : \\ THEODORE WILLIAMS, M.D., F.R.C.P.
}

Clinical Demonstrations of Selected Cases daily (except Saturdays) at 4 p.m.

Lectures daily (except Friday and Saturday) at 5.15 p.m.

The teachers include members of the Staffs of the General and Special Hospitals and Medical Schools of the Metropolis and elsewhere.

The Demonstrations on Friday afternoons at 4 p.m. are devoted to Diseases of the Throat, Nose, Ear and Eye, and during January they are as follows: Jan. 7.-Mr. J. GAY French (Ear, Nose, and Throat). Jan. I4-Dr. William Hill (Ear, Nose, and Throat). Jan. 2i.-Mr. W. Stuart-Low (Ear, Nose, and Throat). Jan. 28.-Mr. R. E. Bickerton (Eye).

Lectures will be given at 5.15 p.m. as follows: Wednesday, Jan. 5.-Dr. James Donelan, "On Suppurations in the Maxillary Antrum." Wednesday, Jan. I2.-Dr. Scanes Spicer, "A New Cardinal Principle in the Treatment of Disease and its application in Disorders of the Nose and Throat." Wednesday, Jan. I9.-Dr. LiEven, "On the Treatment of Syphilis." Jan. 20.-Dr. ANDREW WyLIE, "Foetid Breath."

Annual Subscription, admitting to all Lectures and Demonstrations, One Guinea.

Special Practical Classes are conducted in Otology (Mr. KELson), Laryngology

(Dr. Dundas Grant), and Rhinology (Mr. Stuart-Low), etc.

Pathological Investigations of all kinds are carried out in the Laboratory.

Further Particulars may be obtained from the Medical Superintendent,

Major Vint, M.B., 22, Chenies Street, Gower Street, London, W.C. 


\section{CONTENTS.}

Special Article-

The Anatomy of the Capsule of the Tonsil, and its Significance in the Treatment of Diseases of the 'Tonsil.-G. Seccombe Hetт, M.B., F.R.C.S.-(With Plate)

$\ldots$

...

Clinical Annotation-

A Case of Parasite of External Meatus.-Dr. Hemmeon $\quad \ldots \quad \ldots \quad \ldots \quad 57$

Societies' Proceedings-

Royal Society of Medicine.-Otological Section.-Communication by the President

$$
\text { (1) }
$$

Transactrons of the Socrety of German Larragologists (continued from p. 550).-Communications by Hegener, A. KuTtNer, Killian, HUGO STERN, NADOLECZNY, IMHOFER

Proceedings of the American Laryngologrcal, Rhinological, and Otological Societry (continued from p. 555). - Communications by Eugar M. Holmes, H. O. Reik, Charles W. Richardson, T. Passmore Berens, H. Arrowsmith, Wolff Freudenthal, J. E. $\begin{array}{llllllll}\text { ShePPARD } & \ldots & \ldots & \ldots & \ldots & \ldots & \ldots\end{array}$

International Congress of Medicine at Budapest.-Section of Laryngology and Rhrnologr.-Communications by Srr Ferix Semon, Chiari, Gudck, Massei, Zwillinger, von Eroken, Rethi, SARgNON AND BARLATIER

$\cdots$

Abstracts-

Esophagus.-Two Cases of Esophageal Spasm Diagnosed and Cured by Esophagoscopy.-Impacted Bone that could not be Removed by Esophagoscopy.-Further Cases of Tuberculosis of the Esophagus

Phanynx.-The Enucleation of Tonsils with the Guillotine.-The Care of Children after an Operation upon the Tonsils and Adenoid Tissue. -Suture of the Faucial Pillars for Hæmorrhage following Tonsillectomy.-A Fatality following the Removal of Tonsils and an Adenoid Growth.- Syphilis and Malignant Tumours of the Throat.The Clinical Diagnosis of Tuberculosis of the Tonsils.-Epithelial Pearls of the Vault of the Palate in Relation to the Etiology of Tumonrs of that Region (Illustrated)

Nose.-On the Occurrence of Teeth in the Nasal Cavities.-The Nasal Septum ; Important Points in Anatomy and Submucous Resection.On the Indications and Operation for Deflection of the Nasal Septum

Ear.-The Etiology of Acute Otitis.-Routine Otoscopy in the Febrile Affections of Infancy and Childhood.-Thrombo-phlebitis of the Jugular Vein, and Diffuse Suppurative Meningitis, secondary to an Unrecognised Labyrinthitis; Cranial Autopsy.-Researches on the Pathogenesis of Congenital Syphilitic Deafness.-A Case of Lateral Sinus Thrombosis in which the Klebs-Loeftler Bacillus was present. - The Value of Thyroid Extract in Aural Manifestations of Myxodema

\section{GUIDE TO ADVERTISEMENTS.}

Allen \& Hanburys

Burroughs Welleome \& Co.

Central London Throat and Ear

Hospital ...

Down Bros.

Edwards' Furnishing Warehouses

Foyle, A. L.

\begin{tabular}{|c|c|c|c|}
\hline & & & \\
\hline & Golden Square Throat Hospital & & \\
\hline vi & Good & .. & \\
\hline & $\begin{array}{l}\text { nacal Co. } \\
\text { Itzer }\end{array}$ & & \\
\hline & aduates' College a & and & \\
\hline & & & \\
\hline & Parke Davis \& Co. & & \\
\hline
\end{tabular}




\title{
THE JOURNAL OF LARYNGOLOGY, RHINOLOGY, AND OTOLOGY.
}

Founded in 1887 by MORELL MACKENZIE $a n d$ NORRIS WOLFENDEN.

\begin{abstract}
ARTHUR SANDFORD, M.D., M.Ch.R.U.I.
DUNDAS GRANT, M.A., M.D., F.R.C.S.Eng.

W. MILLIGAN, M.D., M.Ch.

CONTROLLING EDITOR.

DUNDAS GRANT, M.A., M.D., F.R.C.S.Eng.

SUB-EDITOR.

DAN MCKENZIE, M.D., F.R.C.S.E.

WTTH THE CO-OPERATION OP

Drs. Price-Brown (Toronto), Cartaz (Paris), Bryson Delavan (New York), Don (Chicago), DONELAN (London), Clayton Fox (London),

J. S. Fraser (Edinburgh), Gray (Glasgow), Guthrie (Liverpool), Grazzi (Florence), Hicguet (Brussels), Midnlemass Hunt (Liverpool), Hutchison (Brighton), loat (Paris), Kelity (Glasgow), Lacoarret (Toulouse), Lichtwitz (Bordeaux),

Lieven (Aix-la-Chapelle), John N. Mackenzie (Baltimore), Prof. Massei (Naples), McCali. (Bournemouth), Meyjes (Amsterdam), Myles (Neze York),

Holger Mygind (Copenhagen), Chicheie Nourse (London), Porter (St. Louis),

IV. G. Porter (Edinburgh), KNowles Renshaw (Manchester), SACHS (Hamburg),

Sajous (Philadelphia), Señziak (Warsaw), Lindey Seweil (Manchester)

Sota (Seville), SiClair Tilomson (London), Purves Stewart (London),

Hunter Tod (London), Alex. R. Tweede (Nottingham), Woons (Dublin), Wylie (London), Macleon Yearsley (London), and Ziem (Dantzig).
\end{abstract}

JOHN MACINTYRE, M.B., M.Ch., F.R.S.E.

\section{CONTRIBUTORS TO THIS NUMBER}

Dr. Dundas Grant. | Dr. James Adam.

Dr. Watson Williams. Dr. Dan McKenzie.

Dr. JoBsON HORNE.

Dr. Thomas Guthrie.

\section{MEDICAL GRADUATES' COLLEGE}

\section{AND \\ POLYCLINIC,}

\section{2, Chenies Street, Gower Street, London, W.C.}

\author{
HONORARY PRESIDENT: \\ Sir JONATHAN HUTCHINSON, F.R.S., LL.D. \\ PRESIDENT: \\ THEODORE WILLIAMS, M.D., F.R.C.P.
}

Clinical Demonstrations of Selected Cases daily (except Saturdays) at 4 p.m.

Lectures daily (except Friday and Saturday) at 5.1 5 p.m.

The teachers include members of the Staffs of the General and Special Hospitals anc Medical Schools of the Metropolis and elsewhere.

The Demonstrations on Friday afternoons at 4 p.m. are devoted to Diseases of the Throat, Nose, Ear and Eye, and during December are as follows: December 2, Dr. Dan McKenzie (Throat, Nose and Ear). December 9, Dr. Geo. Thompson (Eye). December i6, Dr. StClair Thomson (Throat and Nose). The following lecture will be delivered on Thursday, December 8, at 5.15, on "The Results of Nasal Obstruction," by Mr. Somerville Hastings.

Annual Subscription, admitting to all Lectures and Demonstrations, One Guinea.

Special Practical Classes are conducted in Otology (Mr. Stuart-Low and Mr. Kelson), Laryngology (Dr. Dundas Grant and Mr. H. S. BARwell), and Rhinology (Mr. StuartLow), etc.

Pathological Investigations of all kinds are carried out in the Laboratory.

Further Particulars may be obtained from the Medical Superintendent,

Major Vint, M.B., 22, Chenies Street, Gower Street, London, W.C. 